\title{
CORROSION CHARACTERISTICS OF AN \\ ADDITIVE-MANUFACTURING COBALT-CHROME-WOLFRAM BIOMEDICAL ALLOY UNDER HEAT-TREATED AND MOLYBDENUM-DOPED CONDITIONS
}

\author{
KOROZIJSKE LASTNOSTI TOPLOTNO OBDELANIH IN Z \\ MOLIBDENOM DOPIRANIH Co-Cr-W BIOMEDICINSKIH ZLITIN, \\ IZDELANIH Z DODAJNO TEHNOLOGIJO
}

\author{
Ebuzer Aygul $^{1 *}$, Senai Yalcinkaya1, Yusuf Sahin ${ }^{2}$ \\ ${ }^{1}$ Marmara University, Faculty of Technology, Department of Mechatronics Engineering, 34722, Istanbul, Turkey \\ ${ }^{2}$ Near East University, Faculty of Engineering, Department of Mechanical Engineering, Fahrettin Kerim Gokay Street, Kadikoy, \\ 99138, Mersin, Turkey \\ Prejem rokopisa - received: 2019-11-07; sprejem za objavo - accepted for publication: 2020-03-15
}

doi:10.17222/mit. 2019.272

Two groups of cobalt-chrome-wolfram alloys, Co-Cr-W-Si and Co-Cr-W-Mo-Si, were selected for additive manufacturing. One of these samples was subjected to heat treatment after production under the same conditions. Thus, it is aimed to investigate the effects of heat treatment and molybdenum doping on the corrosion behaviour of cobalt-chrome alloys. The corrosion behaviour of the samples was investigated by using an electrochemical corrosion technique. Ringer's solution was used for the aqueous environment of the electrochemical corrosion technique.

Keywords: heat treatment, molybdenum doped, electrochemical corrosion, ringer solution

Avtorji članka so izbrali dve skupini biomedicinskih zlitin Co-Cr-W-Si in Co-Cr-W-Mo-Si za izdelavo z dodajalno tehnologijo. Eno skupino vzorcev so tudi termično obdelali in na ta način študirali vpliv termične obdelave in dodatka Mo na njihovo obnašanje. Korozijske lastnosti vzorcev so preiskovali z uporabo elektrokemijskih korozijskih tehnik. Uporabili so Ringerjevo raztopino za izvajanje elektrokemijskih korozijskih tehnik v vodnem okolju.

Ključne besede: toplotna obdelava, dopiranje z molibdenom, elektrokemijska korozija, Ringerjeva raztopina

\section{INTRODUCTION}

Biometals are classified in terms of their dynamic and mechanical properties, both against human body tissue and against each other. Metals and alloys are degraded by electrochemical attacks when exposed to an enemy tissue environment. The aggressive aqueous environment in the human body contains various anions such as chloride, phosphate and bicarbonate. Because of the colodic and anodic reactions, the metallic components of the alloy are oxidized to ions and dissolved oxygen is reduced to hydroxide ions. Corrosion-resistant metallic implants are passive. Passive metals have a thin, compact oxide layer that separates ion release on their surfaces. This release may cause allergic and toxic reactions in the body. ${ }^{1,2}$ Co-Cr-based metallic bio-alloys are known for their good corrosion rate, high temperature resistance and good wear resistance. In general, the co-base alloys obtained by the casting method were first introduced in the medical field as a dental implant. Subsequently, many mechanical and dynamic tests in the body environment have shown that Co-based alloys are biocompatible

*Corresponding author's e-mail:

ebuzer.aygul@marmara.edu.tr (Ebuzer Aygul) and can be used as bioimplants. ${ }^{3,4}$ Co-based alloys are strengthened by the addition of $\mathrm{Cr}$, and the addition of Mo results in a fine-grained structure that improves the mechanical properties. $\mathrm{Co}-\mathrm{Cr}$ and $\mathrm{Co}-\mathrm{Cr}-\mathrm{Mo}$ are mainly used in dentistry, newly developed artificial joints, hip and knee joints as prosthetic stem material. The most important feature of co-base alloys is the high corrosion resistance in a chlorine environment due to the high chromium content. The chromium oxide layer (usually $\mathrm{Cr}_{2} \mathrm{O}_{3}$ ) formed on the surface is the element which provides the basic corrosion resistance of Co-based alloys. ${ }^{5}$ Then the content of this alloy is changed by cobalt-chromium-molybdenum (Co-Cr-Mo) alloy, cobalt-nickelchromium-tungsten-iron (Co-Ni-Cr-W-Fe) alloy and cobalt-nickel-chromium-molybdenum $\mathrm{Co}-\mathrm{Ni}-\mathrm{Cr}-\mathrm{Mo}$ ) alloy was developed. The vitalium (Co-Cr-Mo) alloy has been used for many years in dentistry and recently in the production of artificial joints. The Co-Ni-Mo alloy is a newer material and is used in joints under high load (such as knee and hip) and prostheses. ${ }^{6,7}$ The use of cobalt-chromium alloys in the biomedical field dates back to the 1940 s. The materials used are mainly cobalt-chromium-molybdenum based, but are preferred in load bearing hip and joint implants due to their high static and dy- 
E. AYGUL et al.: CORROSION CHARACTERISTICS OF AN ADDITIVE-MANUFACTURING ...

Table 1: The chemical compositions of alloys

\begin{tabular}{|c|c|c|c|c|c|c|}
\hline Element & Cobalt & Chrome & Wolfram & Silicon & Molybdenum & alloys \\
\hline Content $(w / \%)$ & 59 & 25 & 9.5 & 1 & 3,5 & Co-25Cr-9,5W-3,5Mo-1Si \\
Content $(w / \%)$ & $66-67$ & $26-28$ & $8-9$ & 1,5 & - \\
\hline
\end{tabular}

namic strength. While cobalt and chromium form solid melts up to $65 \%$ cobalt, the added chromium makes the structure more resistant and increases its corrosion resistance. Molybdenum, on the other hand, makes an extra contribution to the strength of the structure by showing a grain-reducing effect. ${ }^{8}$ The international American Society for Testing and Materials (ASTM) F75 cast CoCr-Mo alloy is generally known as Vitallium and Haynes 21 and has long been used in the biomedical field. The main feature of this alloy is its high corrosion resistance in a chlorine environment due to its high chromium content. The chromium oxide layer (usually $\mathrm{Cr}_{2} \mathrm{O}_{3}$ ) formed on the surface provides this corrosion resistance. ${ }^{9}$ Among the rapid and layered production techniques, selective laser melting SLM is known to be the most commonly used method for the restoration of dental restorations. ${ }^{10,11}$ SLM, which is supported by CAD/CAM technology, is a production process that melts metal powders with a focused laser beam and produces 3D-CAD data layered. ${ }^{12}$ SLM can produce metal parts with high density precision and good density quality. ${ }^{13}$ Compared to the CAST and CNC technique, the SLM technique provides a smoother surface, shorter machining cycles, fewer internal defects and better compliance with patients. Therefore, SLM for dental restorations appears to be the most suitable manufacturing technology to date. ${ }^{14,15}$

\section{EXPERIMENTAL PART}

In this study, the SLM production method was chosen because of its innovative approach to produce Co-Cr-W-Si and Co-Cr-W-Mo-Si alloys. The SLM manufacturing method is known as the most suitable method for producing dental restorations among the additive-manufacturing production methods. The chemical compositions of the alloys produced in the study are given in Table $\mathbf{1}$.

In biomedical applications, W, Si and Mo additives to cobalt-chrome alloys have been reported to improve the wear and corrosion properties of the alloy, and the Mo additive is known to make the alloy extra fine. The SLM method was used to produce $\mathrm{W}, \mathrm{Si}$ and Mo-doped $\mathrm{Co}-\mathrm{Cr}$ alloys. The samples were produced in the SISMA company's MYSINT 100 Dual Laser machine in a nitrogen gas environment. The metal powders produced (from BEGO and Scheftner Dental Alloys) were supplied. After the alloys were produced by SLM, one sample was heat treated at $1000{ }^{\circ} \mathrm{C}$ for 1 hour. For the heat treatment, a chamber oven of the protherm company was used. Samples produced with SLM are given in Figure 1.
Figure 1a Co-Cr-W-Si alloy produced by SLM method, Figure 1b the annealed Co-Cr-W-Si alloy after it is produced with SLM method, Figure 1c the annealed Co-Cr-W-Mo-Si alloy after it is produced with SLM method,and Figure 1d Co-Cr-W-Mo-Si alloy produced by SLM method. In order to understand the mechanical and corrosive properties of the alloys, the density values were measured and compared with the Archimedes principle, then the microhardness values were measured, and finally the electrochemical corrosion test was performed.

\section{1. Materials and sample preparation}

The initial sizes of the Co-Cr-W-Mo-Si powders supplied by Scheftner Dental Alloys are 30 microns, density of $8.8 \mathrm{~g} / \mathrm{cm}^{3}$ and microhardness values of 345/490 HV. The chemical compositions of the powders are given in Table 1. SLM is the technique chosen to produce these powders. The initial size of the Co-Cr-W-Si alloy was 30 microns, density $8.6 \mathrm{~g} / \mathrm{cm}^{3}$ and micro hardness $470 / 430$ HV.

\subsection{Mechanical property characterization}

The density of the samples was measured using Archimedes' principle. The Vickers hardness (HV) of the samples was performed using a universal microhardness tester (FM-310e) with a load of $100 \mathrm{~g}$ and a residence time of $10 \mathrm{~s}$. Finally, the Mo additive, production technique and the effects of heat treatment on alloys were investigated. By means of Archimedes' principle, the densities of the samples were determined from the verious

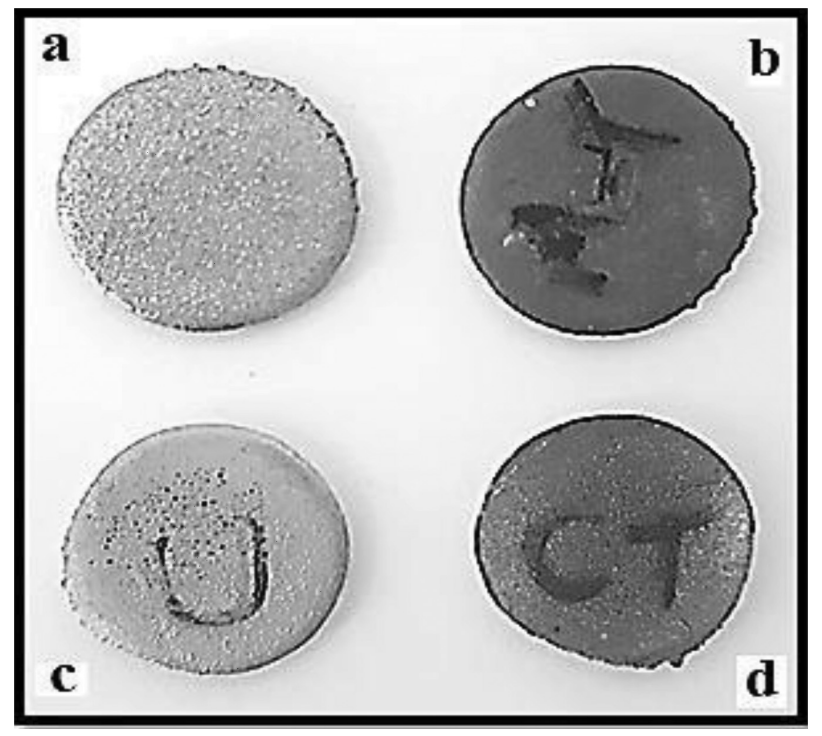

Figure 1: Alloys produced by additive manufacturing (SLM) 
parts of each sample in different atmospheres. In the density-calculation stage, the following formula was used:

$$
D_{\mathrm{g}}=\left\lceil\frac{W_{\mathrm{a}}}{W_{\mathrm{a}}-W_{\mathrm{b}}}\right\rceil \cdot D_{\mathrm{H}_{2} \mathrm{O}}
$$

Where $D_{\mathrm{g}}, W_{\mathrm{a},} W_{\mathrm{b}}$, and $D_{\mathrm{H}_{2} \mathrm{O}}$ are visible density of the sample, weight of the dry sample in air, hanging weight of the sample in water, and water density, respectively.

\section{3. Electrochemical test}

Corrosion is the degradation of metals and their alloys by interacting with their environment. This deterioration may be electrochemical or chemical. Nowadays, many corrosion measurement techniques are available. Among these techniques, the most prominent one is the electrochemical corrosion measurement method according to the others. Electrochemical corrosion is based on the creation and use of anodic and cathodic polarization curves. Our alloys were analysed in a ringer solution of artificial body fluid. One ringer tablet was calcined in $500 \mathrm{~mL}$ of pure water at $121{ }^{\circ} \mathrm{C}$ for $15 \mathrm{~min}$. Typical chemical composition of the tablet used is ammonium chloride 0.00525 ; sodium hydrogen carbonate 0.005 ; calcium chloride- 2 hydrate 0.04 ; potassium chloride 0.00525 ; sodium chloride 1,125. The Bakelite-coated metal alloys are placed in the corrosion apparatus by connecting them as electrodes. Tafel curves and open-circuit voltages were obtained in the potential range determined by using an electrode and a graphite cathode. Reference electrodes used in response to the working electrodes (Co-based alloys prepared) are calomel. Gamry's interface 1000 serial electrochemical analyser is used for all corrosion measurements. Graphite was used as the cathode. The samples were allowed to reach the open-loop potential (Ecorr) within 40 minutes prior to testing. Electrochemical Tafel curve analyses were obtained using Gamry Echem Analyst software. Nowadays, many corrosion measurement techniques are available. Among these techniques, the most prominent one is the electrochemical corrosion measurement method according to the others. In our study, the corrosion rate was determined by the curve drawn on semi-logarithmic scale (Tafel extrapolation method) using current-potential curves. Metallic biomaterials undergo electrochemical degradation as a result of environmental interaction. This negative condi- tion causes corrosion tissue and organ poisoning, but also changes the physical or chemical properties of the material. The electrochemical corrosion test is carried out in an aqueous environment. Ringer's solution, which is close to body fluid, was preferred for aqueous media.

\section{RESULTS}

\subsection{Density and microhardness study}

The calculated density values for as-cast and annealed W-, Si- and Mo-doped Co-Cr alloys were found to be $8.769 \mathrm{~g} / \mathrm{cm}^{3}$ and $8.691 \mathrm{~g} / \mathrm{cm}^{3}$, respectively. It is clear that the production process results in an improvement of $0.4 \% \mathrm{~g} / \mathrm{cm}^{3}$ in the Co-Cr-W-Mo-Si alloy. This ratio is $1.3 \% \mathrm{~g} / \mathrm{cm}^{3}$ in the annealed sample. It is seen that annealing results in an improvement of $0.89 \% \mathrm{~g} / \mathrm{cm}^{3}$ in the sample. Density values of as-cast and annealed samples in the Co-Cr W-Si alloy were measured as $8.56 \mathrm{~g} / \mathrm{cm}^{3}$ and $8.35 \mathrm{~g} / \mathrm{cm}^{3}$, respectively. It is clear that the production process produces an improvement of $0.5 \% \mathrm{~g} / \mathrm{cm}^{3}$ in the Co Cr-W-Si alloy. This ratio appears to be $3 \% \mathrm{~g} / \mathrm{cm}^{3}$ in the annealed sample. It is seen that annealing produces an improvement of $2.5 \% \mathrm{~g} / \mathrm{cm}^{3}$ in the sample. In general, Mo-doped increases the density of the sample and annealing decreases the density of the sample.

The Vickers test for all alloys was carried out at a constant $100 \mathrm{~g}$ load and for $10 \mathrm{~s}$. For as-cast and heattreated samples, 5 hardness measurements were performed on random surfaces. The arithmetic means of the 5 microhardness values were obtained and exhibited in Table 2. As can be seen in Table 3, the microhardness values varied slightly, but the average hardness for the cast samples and heat-treated samples (Co-Cr-W-Si) were about 531, $566 \mathrm{HV}$, respectively. Improvements in heat-treated samples were about $6.2 \% \mathrm{HV}$ in comparison to the same cast alloy. We figured out from the results of Table 2 that the structure in both samples was sufficient. The Vickers test for Co-Cr-W-Mo-Si alloy was carried out at a constant $100 \mathrm{~g}$ load and 10 seconds time. For as-cast and heat-treated samples, 5 hardness measurements were performed on random surfaces. The arithmetic means of the 5 microhardness values were obtained and exhibited in Table 2. As can be seen in Table 2, the microhardness values varied slightly, but the average hardnesses for the cast samples and heat-treated

Table 2: Microhardness values of heat-treated and as-cast samples produced by SLM

\begin{tabular}{|c|c|c|c|c|}
\hline The micro hardness test & Co-Cr-W-Mo-Si & $\begin{array}{c}\text { Heat-treated } \\
\text { Co-Cr-W-Mo-Si }\end{array}$ & $\mathrm{Co}-\mathrm{Cr}-\mathrm{W}-\mathrm{Si}$ & $\begin{array}{l}\text { Heat-treated } \\
\text { Co-Cr-W-Si }\end{array}$ \\
\hline \multirow{5}{*}{$\mathrm{kgf} / \mathrm{mm}^{2},(\mathrm{HV})$} & 371.3 & 330.1 & 513.4 & 590.9 \\
\hline & 348 & 440.9 & 515.7 & 579.1 \\
\hline & 386 & 449.6 & 575.9 & 565.8 \\
\hline & 398.8 & 452.7 & 533.2 & 545.6 \\
\hline & 432.2 & 485.5 & 517.5 & 551.7 \\
\hline Average value & 387.26 & 431.76 & 531.14 & 566.62 \\
\hline
\end{tabular}


Table 3: The corrosions values of samples

\begin{tabular}{|l|c|c|c|}
\hline \multicolumn{1}{|c|}{ Samples } & Co-Cr-W-Mo-Si & $\begin{array}{c}\text { Heat-treated } \\
\text { Co-Cr-W-Mo-Si }\end{array}$ & $\begin{array}{c}\text { Heat-treated } \\
\text { Co-Cr-W-Si }\end{array}$ \\
\hline$I_{\text {CORR }},(\mathrm{nA})$ & 29.30 & 12.80 & 69.20 \\
\hline$E_{\text {CORR }},(\mathrm{mV})$ & 50.70 & -145.0 & -139.0 \\
\hline Corrosion rate, $(\mathrm{mpy})$ & 4.503 & $7.33 \mathrm{e}-02$ & 1.125 \\
\hline
\end{tabular}

samples were about $387,431 \mathrm{HV}$, respectively. Improvements in the heat-treated samples were about $10.3 \% \mathrm{HV}$ in comparison to the same cast alloy. We figured out from the results of Table 2 that the structure in both samples was sufficient.

\subsection{Electrochemical test study}

Figure 2 shows the open-circuit potential measurements of the samples in the ringer solution for $40 \mathrm{~min}$. The annealed Co-Cr W-Si alloy was thermodynamically stable during the measurement period. A relatively stable thermodynamic behaviour is also observed in the annealed Co-Cr-W-Mo-Si alloy. Open-circuit potentials are approximately $8 \mathrm{mV}$ for Co-Cr-W-Mo-Si alloy, $-65 \mathrm{mV}$ for annealed $\mathrm{Co}$ Cr-W-Mo-Si alloy, $41 \mathrm{mV}$ for $\mathrm{Co}-\mathrm{Cr}-\mathrm{W}-\mathrm{Si}$ alloy and annealed Co-Cr. It was measured as $60 \mathrm{mV}$ for the W-Si alloy. The Co-Cr-W Mo-Si alloy deviated in a positive direction and completed the measurement at higher values than it started. Samples that exhibit such behaviour are caused by a protective oxide layer formed on their surface. The Co-Cr-W-Si alloy sample exhibits a different behaviour than other alloys. Potential measurements show a steady behaviour in the first $150 \mathrm{sec}$, while the potential increases rapidly with time. It can be emphasized that a thin layer formed over time dissolves rapidly. As a result of the measurement, the thermodynamic stability of the equilibrium with the solution was not fully achieved.

Figure 3 shows the graphical data resulting from the Tafel analysis. The corrosion potential values of the Co-Cr-W-Si and annealed Co-Cr-W-Mo-Si coded sam-

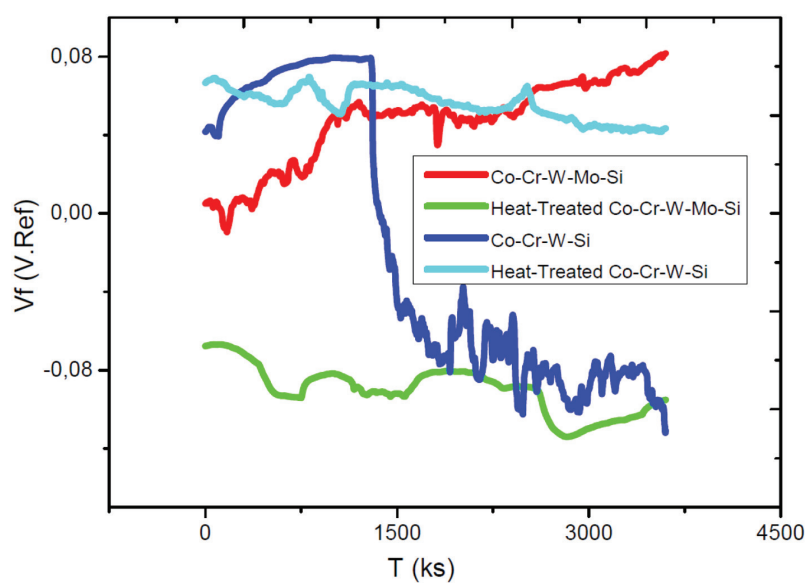

Figure 2: Open-circuit voltage curves of selective laser melted Co-Cr-W-Mo-Si and Co-Cr-W-Mo alloys ples were very close to each other, while the annealed Co-Cr-W-Si and Co-Cr-W-Mo-Si coded samples had corrosion potential values of each other. In this case, the most important parameter determining the rate of corrosion is beta $\mathrm{A}$ and beta $\mathrm{C}$ values. Unstable data values of Co-Cr-W-Si and annealed Co Cr-W-Mo-Si coded samples are seen in the anodic part. Since the anodic part in most samples is opposed to dissolution, surface dissolution is observed due to the rapid occurrence. When compared according to corrosion rates, the highest ratio is 4.809 mpy annealed Co-Cr-W-Si alloy and the smallest value is $11.11 \mathrm{e}-3$ mpy Co-Cr-W-Mo-Si alloy. The Co-Cr-W-Si alloy has a value of 2.003 mpy and annealed Co-Cr-W Mo-Si 410.5e-3 mpy. The most important values determining corrosion rates are; corrosion potential $\left(E_{\mathrm{CORR}}\right)$, corrosion current $\left(I_{\mathrm{CORR}}\right)$ and corrosion rates (mpy) are given in Table 3.

\section{DISCUSSION}

Although cobalt-chrome alloys were discovered as biomaterials before titanium and their alloys, their use as biomaterials after the discovery of titanium and its alloys was pushed to the background. However, the use of cobalt-chromium alloys has become widespread due to the development of production techniques. Especially cobalt-chromium-based biomaterials called Coarse ship, which consists of a total of 5 metals Co-Cr-W-Mo Si alloy and including many cobalt-chromium alloys has come to be easily produced by additive manufacturing techniques. Cobalt-chromium alloys are being used in

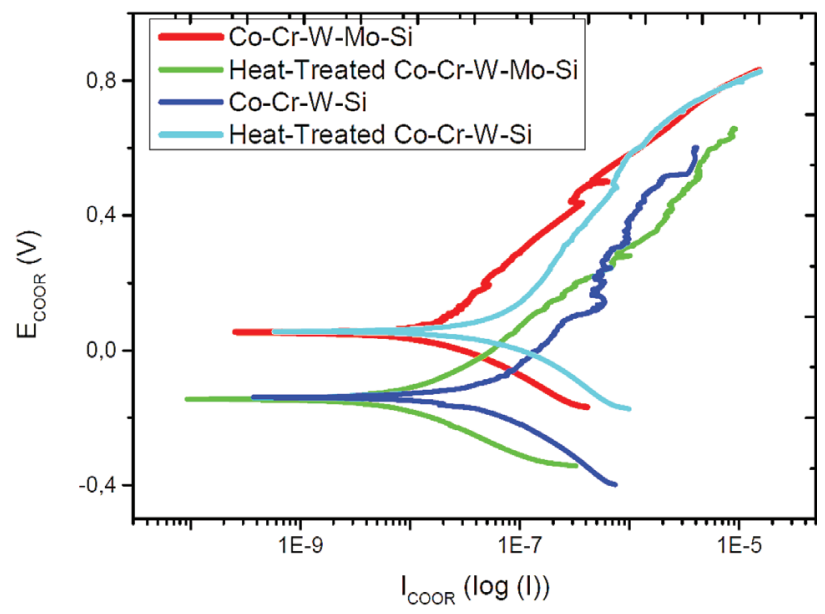

Figure 3: The polarization curves of selective laser melted $\mathrm{Co}-\mathrm{Cr}-$ W-Mo-Si and Co-Cr-W-Mo specimens in Ringer solution 
biomaterials science at a very high rate nowadays thanks to the ease of production with additive-manufacturing production technique. The variability of the production technique, secondary heating processes or the addition of alloys of different metal types can lead to serious changes in the mechanical properties of the material. Especially for biomaterials which are in constant contact with tissue and body fluids, good corrosion resistance is the most important parameter. In this study, Mo-doped Co-Cr-W-Mo-Si alloy stands out with suitable mechanical properties in both tested alloys. Mo-doped was found to improve the corrosion and microhardness values of the alloy. Lu et al., in their corrosion study for $\mathrm{Co}-\mathrm{Cr}-\mathrm{W}-\mathrm{Si}$ alloy, it is very important that the apparent thin plate degradation seen in the Tafel extrapolation curves does not occur in ours, but unstable data values were observed in our study. ${ }^{16}$ L. Zeng et al. ${ }^{17}$ suggested that the Co-CrMo alloy exhibits similar corrosion behaviour in different production techniques. ${ }^{17}$ In addition, secondary heating process applied after production increased the microhardness and corrosion rate value just like our study and decreased the corrosion current $I_{\mathrm{CORR}}$ value.

\section{CONCLUSIONS}

Cobalt-chromium alloys are known in the medical field for their good wear and corrosion resistance. Co-Cr-W-Si and Co-Cr-W-Mo-Si alloys are the two most popular members of the cobalt-chromium alloy family. The Mo additive has been reported to render the alloy fine. Additive-manufacturing production techniques are highly skilled in producing cobalt chromium alloys. The findings obtained in this study are listed as follows:

- The SLM production technique improved the density of Co-Cr-W-Mo-Si alloy by $0.4 \% \mathrm{~g} / \mathrm{cm}^{3}$. This ratio was found to be $1.3 \% \mathrm{~g} / \mathrm{cm}^{3}$ for the annealed sample of the Co-Cr-W-Mo-Si alloy.

- Heat-treated Co-Cr-W-Mo-Si alloy shows an improvement of $0.89 \% \mathrm{~g} / \mathrm{cm}^{3}$.

- The SLM production technique showed an improvement of $0.5 \% \mathrm{~g} / \mathrm{cm}^{3}$ in the density ratio of the $\mathrm{Co}-\mathrm{Cr}-\mathrm{W}-\mathrm{Si}$ alloy. This ratio was found to be $3 \%$ $\mathrm{g} / \mathrm{cm}^{3}$ for the annealed sample of the Co-Cr-W-Si alloy.

- Heat-treated Co-Cr-W-Si alloy shows an improvement of $2.5 \% \mathrm{~g} / \mathrm{cm}^{3}$.

- It has been found that annealing has a density-reducing effect on both alloys. The Mo additive appears to increase the density value.

- The annealing process increased the microhardness value in both alloys.

- It is seen that the microhardness value of Mo-doped alloy is lower.

- Annealing Co-Cr-W-Mo-Si while increasing the microhardness value of the alloy by $10.3 \% \mathrm{HV}$. This ratio is $6.2 \% \mathrm{HV}$ in the $\mathrm{Co}-\mathrm{Cr}-\mathrm{W}-\mathrm{Si}$ alloy.
- When the corrosion behaviour of the alloys is examined, the annealed Co-Cr-W Si alloy's thermodynamically stable behaviour during the measurement period of the open-circuit voltage, the potential measurements of the Co-Cr-W-Si alloy behave almost steady in the first $150 \mathrm{sec}$ while the potential increases rapidly with time.

The annealing process increases the corrosion rate (mpy) in both samples.

When compared according to corrosion rates (mpy), the highest ratio is 4.809 mpy annealed Co-Cr-W-Si alloy and the smallest value belongs to Co-Cr-W-Mo-Si alloy with $11.11 \mathrm{e}-3 \mathrm{mpy}$. The Co-Cr-W-Si alloy has a value of $2.003 \mathrm{mpy}$ and annealed Co-Cr-W-Mo-Si 410.5e-3 mpy.

Cobalt-chromium alloys attract attention with their suitability to the additive-manufacturing production process. Especially, the molybdenum-doped Co-Cr-W-Si alloy has a good static and dynamic properties. With the advantages of the manufacturing process, it is obvious that this alloy will attract more attention in biomedical science.

\section{REFERENCES}

${ }^{1}$ C. Aparicio, F. J. Gil, C. Fonseca, M. Barbosa, J. A. Planell, Corrosion behaviour of commercially pure titanium shot blasted with different materials and sizes of shot particles for dental implant applications, Biomaterials, (2003), 24(2), 263-273, doi:10.1016/S01429612(02)00314-9

${ }^{2}$ V. Hybasek, et al, Mechanical properties, corrosion behaviour and biocompatibility of TiNbTaSn for dentistry, Materials Research Express, (2020), 7.1, 015403, doi:10.1016/S0142-9612(01)00328-3

${ }^{3}$ D. Ionita, I. Man, I. Demetrescu, The behaviour of electrochemical deposition of phosphate coating on CoCr bio alloys, In Key Engineering Materials (Vol. 330, pp. 545-548), Trans Tech Publications, (2007), doi:10.4028/www.scientific.net/KEM.330-332.545

${ }^{4}$ S. Karimi, T. Nickchi, A. Alfantazi, Effects of bovine serum albumin on the corrosion behaviour of AISI $316 \mathrm{~L}, \mathrm{Co}-28 \mathrm{Cr}-6 \mathrm{Mo}$, and Ti-6Al-4V alloys in phosphate buffered saline solutions. Corrosion Science, (2011), 53(10), 3262-3272, doi:10.1016/j.corsci.2011. 06.009

${ }^{5}$ J. Bolton, X. Hu, In vitro corrosion testing of PVD coatings applied to a surgical grade $\mathrm{Co}-\mathrm{Cr}-\mathrm{Mo}$ alloy, Journal of Materials Science: Materials in Medicine, (2002) 13(6), 567-574, doi:10.1023/ A:1015126810485

${ }^{6}$ R. J. Joseyphus, T. Matsumoto, H. Takahashi, D. Kodama, K. Tohji, B. Jeyadevan, Designed synthesis of cobalt and its alloys by polyol process, Journal of Solid State Chemistry, (2007), 180(11), 3008-3018, doi:10.1016/j.jssc.2007.07.024

${ }^{7}$ J. A. Disegi, R. L. Kennedy, R. Pilliar, (1999, October). Cobalt-base alloys for biomedical applications, Danvers: ASTM. ISBN 0-81312608-5

${ }^{8}$ T. Matković, P. Matković, J. Malina, Effects of Ni and Mo on the microstructure and some other properties of $\mathrm{Co}-\mathrm{Cr}$ dental alloys, Journal of Alloys and Compounds, (2004), 366(1-2), 293-297, doi:10.1016/j.jallcom.2003.07.004

${ }^{9}$ A. Kocijan, I. Milošev, B. Pihlar, Cobalt-based alloys for orthopaedic applications studied by electrochemical and XPS analysis, Journal of Materials Science: Materials in Medicine, (2004), 15(6), 643-650, doi:10.1023/B:JMSM.0000030204.08616.3d

${ }^{10}$ T. Koutsoukis, S. Zinelis, G. Eliades, K. Al-Wazzan, M. A. Rifaiy, Y. S. Al Jabbari, Selective laser melting technique of Co-Cr dental al- 


\section{E. AYGUL et al.: CORROSION CHARACTERISTICS OF AN ADDITIVE-MANUFACTURING ...}

loys: a review of structure and properties and comparative analysis with other available techniques, Journal of Prosthodontics, (2015), 24(4), 303-312, doi:10.1111/jopr.12268

${ }^{11}$ B. Vandenbroucke, J. P. Kruth, Selective laser melting of biocompatible metals for rapid manufacturing of medical parts, Rapid Prototyping Journal, (2007), 13(4), 196-203, doi:10.1108/ 13552540710776142

${ }^{12}$ K. A. Mumtaz, P. Erasenthiran, N. Hopkinson, High density selective laser melting of Waspaloy®, Journal of materials processing technology, (2008), 195(1-3), 77-87, doi:10.1016/j.jmatprotec.2007.04.117

${ }^{13}$ B. Zhang, Q. Huang, Y. Gao, P. Luo, C. Zhao, Preliminary study on some properties of $\mathrm{Co}-\mathrm{Cr}$ dental alloy formed by selective laser melting technique, Journal of Wuhan University of Technology-Mater. Sci. Ed., (2012), 27(4), 665-668, doi:10.1007/s11595-012-0525-0

${ }^{14}$ A. Takaichi, T. Nakamoto, N. Joko, N. Nomura, Y. Tsutsumi, S. Migita, Y. Igarashi, Microstructures and mechanical properties of
Co-29Cr-6Mo alloy fabricated by selective laser melting process for dental applications, Journal of the mechanical behavior of biomedical materials, (2013), 21, 67-76, doi:10.1016/j.jmbbm.2013.01.021

${ }^{15}$ J. P. Kruth, G. Levy, F. Klocke, T. H. C. Childs, Consolidation phenomena in laser and powder-bed based layered manufacturing, CIRP annals, (2007), 56(2), 730-759, doi:10.1016/j.cirp.2007.10.004

${ }^{16}$ Y. Lu, S. Wu, Y. Gan, J. Li, C. Zhao, D. Zhuo, J. Lin, Investigation on the microstructure, mechanical property and corrosion behavior of the selective laser melted $\mathrm{CoCrW}$ alloy for dental application, Materials Science and Engineering, (2015), C, 49, 517-525, doi:10.1016/ j.msec.2015.01.023

${ }^{17}$ L. Zeng, N. Xiang, B. Wei, A comparison of corrosion resistance of cobalt-chromium-molybdenum metal ceramic alloy fabricated with selective laser melting and traditional processing, The Journal of prosthetic dentistry, (2014), 112(5), 1217-1224, doi:10.1016/ j.prosdent.2014.03.018 